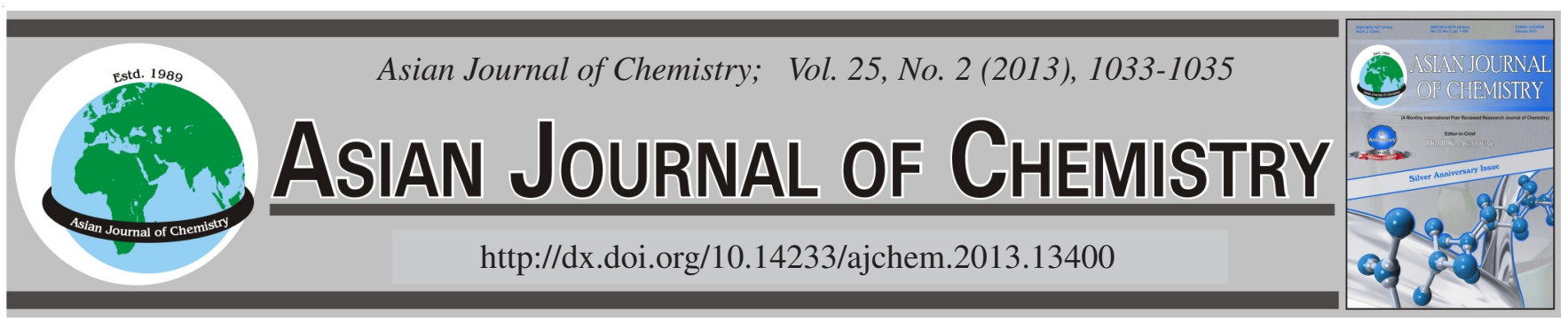

\title{
Adsorption of Carbamazepine on the Adsorbent Produced from Spent Bleaching Earth
}

Mehmet Mahramanlioglu* and Ozge Ozgen Onnar

Istanbul University, Engineering Faculty, Department of Chemistry, Avcilar 34320, Istanbul, Turkey

*Corresponding author: E-mail: mehmah@istanbul.edu.tr

The adsorption of carbamazepine on the adsorbent produced from spent bleaching earth was studied as a function of time, $\mathrm{pH}$ and initial concentration. The adsorption equilibrium was achieved within $1 \mathrm{~h}$ and the adsorption kinetics was found to obey the first-order Lagergren equation. The rate constants and intraparticle diffusion constants were calculated. It was seen that $\mathrm{pH}$ effect on the adsorption of carbamazepine is not very significant. It was concluded that activated carbon produced from spent bleaching earth can be considered as an effective adsorbent for removing carbamazepine.

Key Words: Spent bleaching earth, Carbamazepine, Adsorption.

\section{INTRODUCTION}

Carbamazepine is an active antibiotic compound is used in the pharmaceutical industry. Pharmaceuticals have been of tremendous benefit to our society for treatment and prevention of illnesses are continuously released to the environment by domestic wastewater effluents ${ }^{1-9}$. Removal of even low concentrations of antibiotic agents in the environment is of great concern to scientists due to proliferation of antibiotic agents. Carbamazepine is inert to the biological treatment process ${ }^{1,4,10-15}$. It was reported that in order to remove several organic pollutants, many methods such as adsorption, biodegradation, ion exchange, ozonization, electrochemical oxidation, have been used ${ }^{16,17}$. Among these methods, adsorption is a promising method since adsorption processes produce good quality effluents and is a very effective process. Very less reports are available in literature on the adsorption of carbamazepine and therefore it is necessary to study the adsorption of carbamazepine by different adsorbents. Activated carbon has been used extensively as an adsorbent treatment systems since it has a high surface area and good porosity. However, activated carbon has some disadvantages, since its price and regeneration cost are high. Therefore low cost alternatives are being continously investigated. A number of materials including activated carbon produced from agricultural waste materials, tree fern, orange peel, montmrollonite, orange peel, chitosan, egg shell, coffee residue, used tires, brick powder, coal mining waste and adsorbent from spent bleaching earth have been reported for the removal of several organic or inorganic pollutants ${ }^{16,17}$. In our laboratory, new adsorbents have been produced from cheap materials such as used tires ${ }^{18,19}$, spent bleaching earth ${ }^{20-22}$ and coffee residue ${ }^{23}$, contaminated soil ${ }^{24}$. They have shown a high capacity for some organic and inorganic pollutants. In this study, spent bleaching earth that is a solid waste from edible oil processing industry was chosen as a raw material for the adsorption of carbamazepine. The aim of this study is to produce an adsorbent from spent bleaching earth and to use the adsorbent produced from spent bleaching earth in the removal of carbamazepine from aqueous solutions.

\section{EXPERIMENTAL}

Preparation of the adsorbent: Adsorbents were prepared according to the procedure described by Mahramanlioglu and Ozgen and by Mahramanlioglu et al. ${ }^{16,17}$.

Adsorption experiments: All the solutions in this study were prepared using double distilled water. Carbamazepine was obtained from Sigma. The $\mathrm{pH}$ of solutions was adjusted either with $0.01 \mathrm{~N} \mathrm{HCl}$ or $0.01 \mathrm{~N} \mathrm{NaOH}$.

Batch adsorption experiments were carried out at $20^{\circ} \mathrm{C}$ by shaking a known amount of adsorbent and carbamazepine solutions of desired concentrations and $\mathrm{pH}$ in different glass flasks in a shaking thermostat machine. At the end of predetermined time intervals, samples were withdrawn and centrifuged. The concentration of carbamazepine was determined using spectroscopic method.

\section{RESULTS AND DISCUSSION}

Adsorption kinetics: The adsorption rate constants for carbamazepine was determined from the following Lagergren equation: 


$$
\ln \left(\mathrm{q}_{\mathrm{e}}-\mathrm{q}\right)=\ln \mathrm{q}_{\mathrm{e}}-\mathrm{k}_{\mathrm{a}} \mathrm{t}
$$

where, $\mathrm{q}_{\mathrm{e}}$ and $\mathrm{q}$ (both in $\mathrm{mg} \mathrm{g}^{-1}$ ) are the amount of carbamazepine adsorbed per unit mass of adsorbent at equilibrium and time, $\mathrm{t}$, respectively and $\mathrm{k}_{\mathrm{a}}$ is the rate constant $\left(\mathrm{min}^{-1}\right)$. The value of $\mathrm{k}_{\mathrm{a}}$ was calculated from the slope of linear plot of $\mathrm{ln}$ $\left(\mathrm{q}_{\mathrm{e}}-\mathrm{q}\right)$ versus time (Fig. 1). The adsorption rate constants for the initial concentrations of 10 and $18 \mathrm{mg} \mathrm{dm}^{-3}$ were given in Table-1.

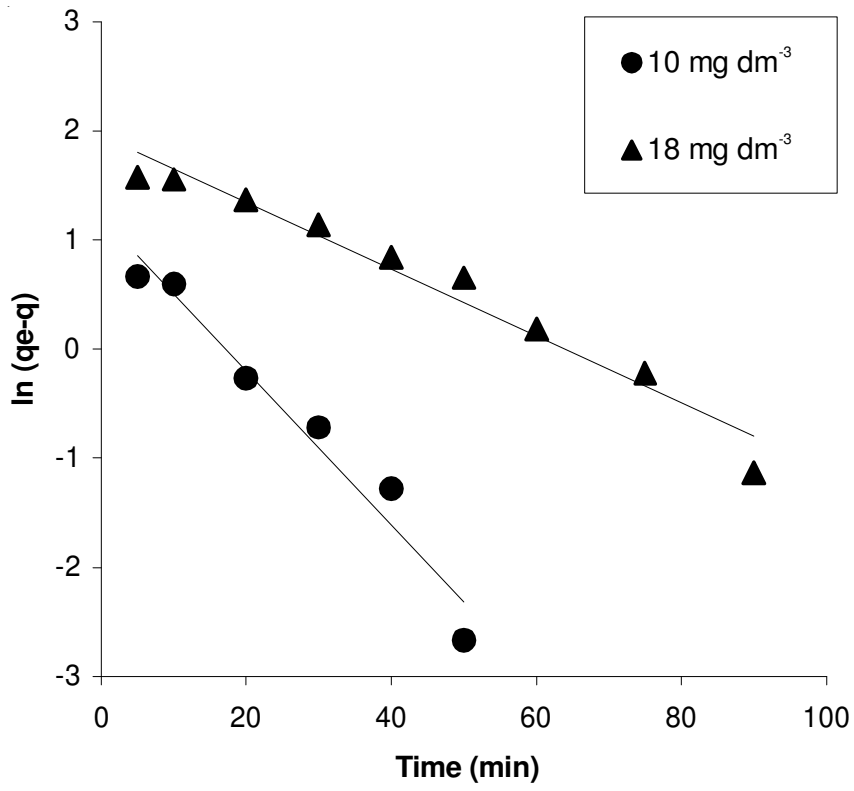

Fig. 1. Lagergren plots for the adsorption of carbamazepine for the concentrations of $10 \mathrm{mg} \mathrm{dm}^{-3}$ and $18 \mathrm{mg} \mathrm{dm}^{-3}$

\begin{tabular}{|c|c|c|c|c|c|}
\hline \multicolumn{6}{|c|}{$\begin{array}{c}\text { TABLE-1 } \\
\text { CONSTANTS OF LAGERGREN EQUATION, INTRAPARTICLE } \\
\text { DIFFUSION AND THE LANGMUIR ISOTHERM OF } \\
\text { CARBAMAZEPINE ADSORPTION ON THE SBE }\end{array}$} \\
\hline \multicolumn{2}{|c|}{$\begin{array}{c}\text { Lagergren constants } \\
\mathrm{k}_{\mathrm{a}}\left(\mathrm{min}^{-1}\right)\end{array}$} & \multicolumn{2}{|c|}{$\begin{array}{l}\text { Intraparticle constants } \\
\mathrm{k}_{\text {int }}\left(\mathrm{mg} \mathrm{g}^{-1} \mathrm{~min}^{-0.5}\right)\end{array}$} & \multicolumn{2}{|c|}{$\begin{array}{l}\text { Langmuir } \\
\text { constants }\end{array}$} \\
\hline $\begin{array}{c}10 \mathrm{mg} \\
\mathrm{dm}^{-3}\end{array}$ & $\begin{array}{c}18 \mathrm{mg} \\
\mathrm{dm}^{-3}\end{array}$ & $\begin{array}{c}10 \mathrm{mg} \\
\mathrm{dm}^{-3}\end{array}$ & $\begin{array}{c}18 \mathrm{mg} \\
\mathrm{dm}^{-3}\end{array}$ & $\begin{array}{c}\mathrm{Q}_{0}(\mathrm{mg} \\
\left.\mathrm{g}^{-1}\right)\end{array}$ & \\
\hline 0.0705 & 0.0306 & 0.180 & 0.626 & 22.78 & 2.64 \\
\hline
\end{tabular}

Intraparticle diffusion: Besides the adsorption at the outer surface of the adsorbents, the solute molecules can also diffuse into the interior of the porous adsorbent. In order to calculate the rate constant of intraparticle diffusion, the following equation was used.

$$
\mathrm{q}=\mathrm{k}_{\text {int }} \mathrm{t}^{1 / 2}
$$

where, $\mathrm{k}_{\text {int }}\left(\mathrm{mg} \mathrm{g}^{-1} \min ^{-0.5}\right)$ is the intraparticle diffusion rate constant. Fig. 2 shows that there is an initially curved portion and the subsequent linear portion. The former indicates the film diffusion and the latter indicates the intraparticle diffusion. The values of $\mathrm{k}_{\text {int }}$ were obtained from the slope of linear portion of the curve. The values of $k_{\text {int }}$ for carbamazepine were given in Table-1. The linear portion of the curves don't pass through the origin indicating that intraparticle diffussion is not only rate controlling step for all the solute. Fig. 2 shows that both the film diffusion and intraparticle diffusion contribute to the rate determining step.

pH effect: The equilibrium concentration of carbamazepine as a function of $\mathrm{pH}$ was studied at different $\mathrm{pH}$ ranging from 2.89 to 8.88 (Fig. 3). Fig. 3 shows that the equilibrium concentration is not significantly affected by the change of $\mathrm{pH}$ values. This can be explained by the fact that carbamazepine is a base with a pKa value of 2.3 and it is neutrally charged at the $\mathrm{pH}$ range of the experiment ${ }^{10}$. Similar results were reported for the removal of carbamazepine by nanofiltration membranes ${ }^{10}$.

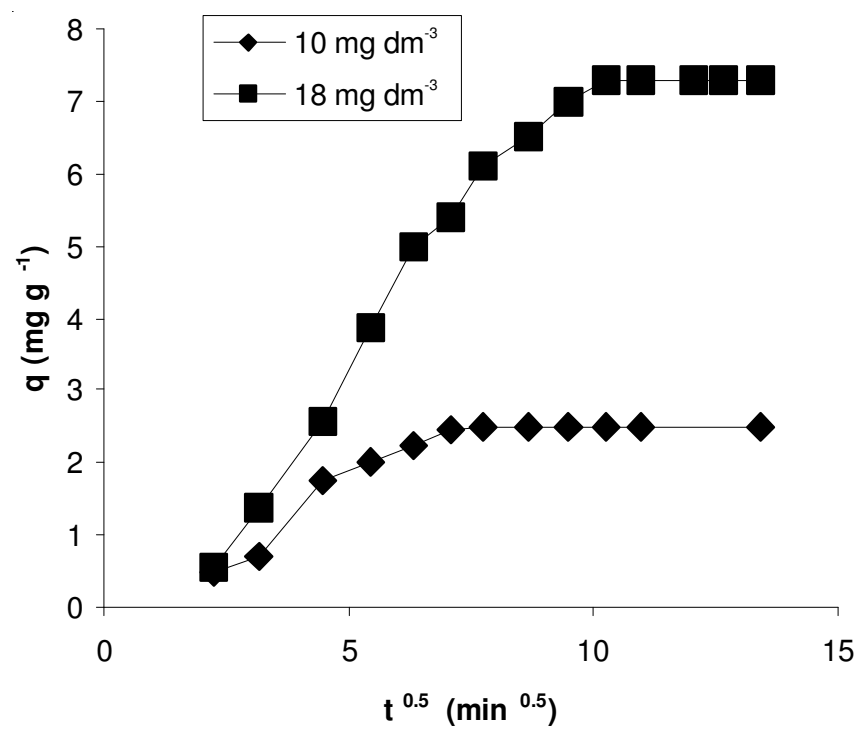

Fig. 2. Intraparticle diffusion for the adsorption of carbamazepine for the concentrations of $10 \mathrm{mg} \mathrm{dm}^{-3}$ and $18 \mathrm{mg} \mathrm{dm}^{-3}$

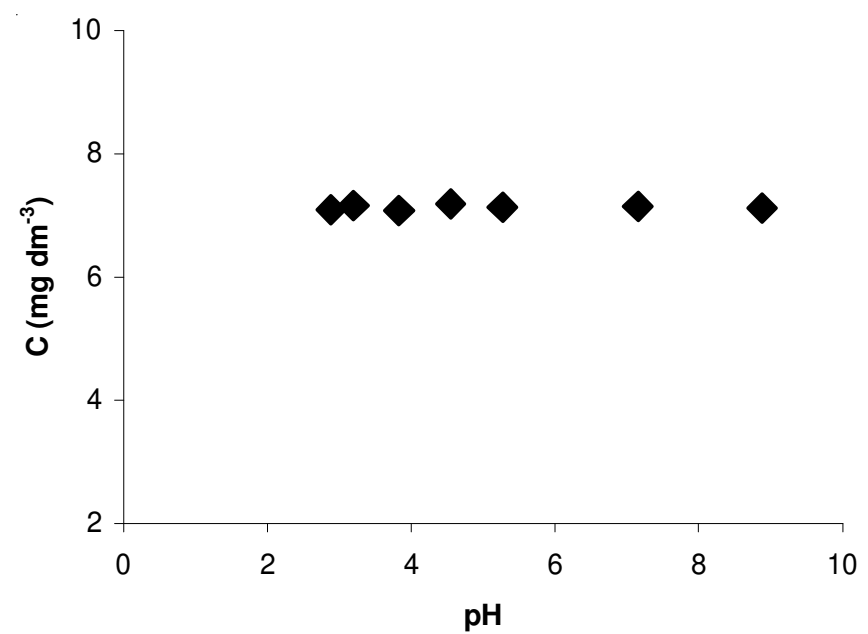

Fig. 3. Equilibrium concentration of carbamazepine as a function of $\mathrm{pH}$ (initial concentration, $10 \mathrm{mg} \mathrm{dm}^{-3}$ )

Adsorption isotherm: In order to quantify adsorption capacity for both solute, Langmuir equation was applied. This equation can be given as follows:

$$
\mathrm{C} / \mathrm{q}=\mathrm{C} / \mathrm{Q}_{0}+1 / \mathrm{Q}_{0} \mathrm{~b}
$$

where, $\mathrm{C}$ and $\mathrm{q}$ are equilibrium solute concentration $\left(\mathrm{mg} \mathrm{dm}^{-3}\right)$ and equilibrium adsorption capacity, respectively $\left(\mathrm{mg} \mathrm{g}^{-1}\right)$. $\mathrm{Q}_{0}$ and $b$ are the Langmuir constants representing adsorption capacity $\left(\mathrm{mg} \mathrm{g}^{-1}\right)$ and energy of adsorption $\left(\mathrm{dm}^{3} \mathrm{mg}^{-1}\right)$, respectively.

The value of $\mathrm{Q}_{0}$ and $\mathrm{b}$ were calculated from the slope and intercept of the linear plot of $\mathrm{C} / \mathrm{q}$ versus $\mathrm{C}$ and were given in Fig. 4 (Table-1).

Giles isotherm: Fig. 5 shows the Giles isotherm for carbamazepine. According to Giles classification in the case 
of carbamazepine, the shape of the obtained isotherm shows $\mathrm{H}_{2}$ isotherm. This result shows that the Giles isotherm for carbamazepine has the subgroup 2. According to $\mathrm{H}_{2}$ isotherm, the initial curve shows that sites in the substrate are filled and it becomes increasingly difficult for a bombarding solute molecule to find a vacant site available and it is not possible to find a vacant site in the region of plateau ${ }^{25}$.

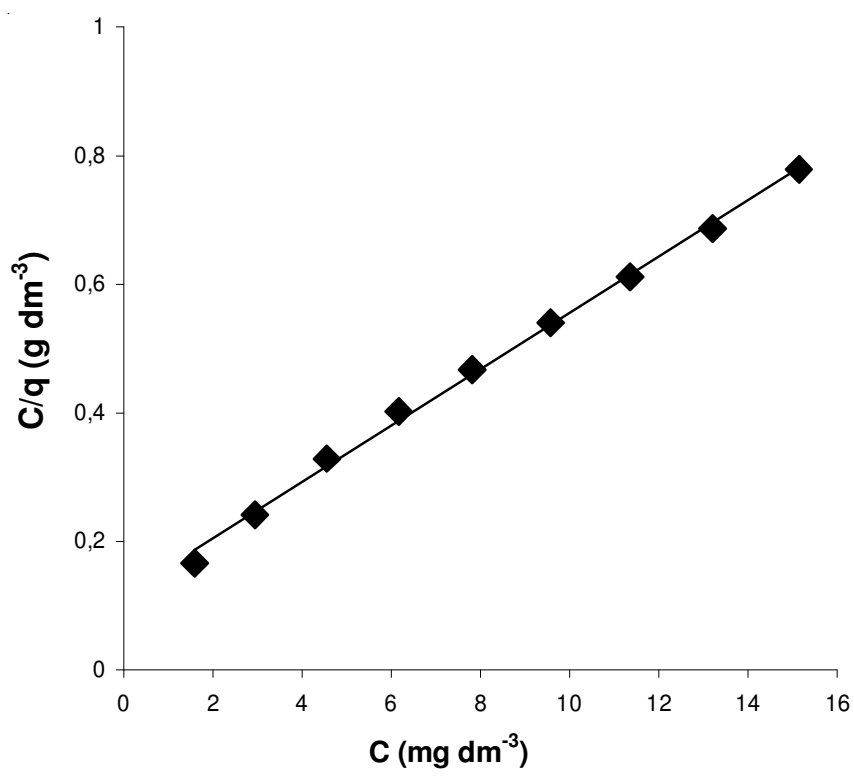

Fig. 4. Langmuir isotherm of the adsorption of carbamazepine

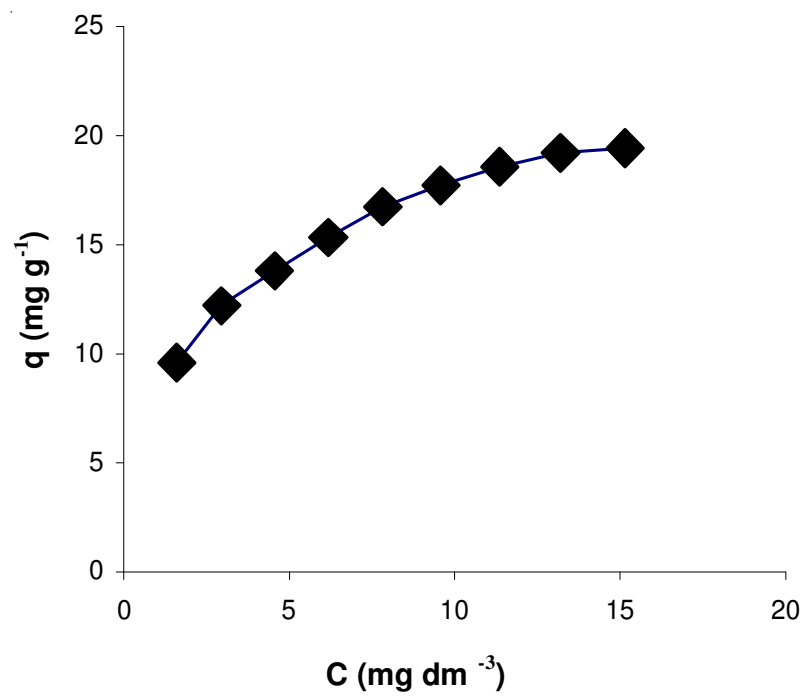

Fig. 5. Giles isotherm of the adsorption of carbamazapine

\section{Conclusion}

The adsorption of carbamazepine on the adsorbent produced from spent bleaching earth was studied. The adsorption process followed a first order Lagergren equation.
Equilibrium data fit well the Langmuir isotherm. The results of kinetic studies showed that both film diffusion and intraparticle diffusion contribute to the rate determining step. The $\mathrm{pH}$ effect on the adsorption of carbamazepine on the adsorbent produced from spent bleaching earth was not very significant. According to the Giles classification, the shape of the obtained isotherm showed $\mathrm{H}_{2}$ isotherm.

\section{ACKNOWLEDGEMENTS}

This study was supported by Research Fund of Istanbul University. Project Number: UDP-7664/10062010

\section{REFERENCES}

1. D. Vogna, R. Marotta, R. Andreozzi, A. Napolitano and M. d'Ischia, Chemosphere, 54, 497 (2004).

2. N. Nakada, T. Tanishima, H. Shinohara, K. Kiri and H. Takada, Water Res., 40, 3297 (2006).

3. S.A. Snyder, S. Adham, A.M. Redding, F.S. Cannon, J. DeCarolis, J. Openheimer, E.C. Wert and Y. Yoon, Desalination, 202, 156 (2006).

4. Scheytt, P. Mersmann, R. Lindstädt and T. Heberer, Chemosphere, 60, 245 (2005).

5. A.S. Mestre, J. Pires, J.M.F. Nogueira, J.B. Parra, A.P. Carvalho and C.O. Ania, Bioresour. Technol., 100, 1720 (2009).

6. A.S. Mestre, J. Pires, J.M.F. Nogueira and A.P. Carvalho, Carbon, 45, 1979 (2007).

7. M. Gros, M. Petrovic, A. Ginebreda and D. Barceló, Environ. Int., 36, 15 (2010).

8. I. Koyuncu, O.A. Arikan, M.R. Wiesner and C. Rice, J. Membr. Sci., 309, 94 (2008).

9. A. Ghauch, A. Tuqan and H.A. Assi, Environ. Pollut., 157, 1626 (2009).

10. L.D. Nghiem, A.I. Schafer and D. Elimelech, Environ. Sci. Technol., 39, 7698 (2005).

11. Z. Yu, S. Pldszus and P.M. Huck, Water Res., 42, 2873 (2008).

12. R. Andreozzi, R. Marotta, G. Pinto and A. Pollio, Water Res., 36, 2869 (2002).

13. Y. Zhang and S.U. Geißen, Chemosphere, 80, 1345 (2010).

14. M. Clara, B. Strenn and N. Kreuzinger, Water Res., 38, 947 (2004).

15. A.V. Dordio, A.J.E. Candeivas, A.P. Pinto, C. Teixeira da Costa and A.J.P. Carvalho, Ecol. Eng., 35, 290 (2009).

16. M. Mahramanlioglu and O. Ozgen, Asian J. Chem., 21, 635 (2009).

17. M. Mahramanlioglu, O. Ozgen, A. Cinarli and I. Kizilcikli, Asian J. Chem., 22, 1428 (2010).

18. M. Mahramanlioglu, J. Radioanal. Nucl. Chem., 256, 99 (2003).

19. M. Mahramanlioglu, I.O. Bicer, T. Misirli, E. Caliskan and S. Gül and C. Misirli, Fresenius Environ. Bull., 15(9b), 1150 (2006).

20. M. Mahramanlioglu, I. Kizilcikli, I.O. Bicer and M. Tuncay, J. Environ. Sci. Health B, 35, 187 (2000).

21. M. Mahramanlioglu, I. Kizilcikli and I.O. Bicer, J. Fluorine Chem., 115, 41 (2002).

22. M. Mahramanlioglu, I. Kizilcikli, I.O. Bicer and M. Tuncay, J. Environ. Sci. Health B, 38, 813 (2003).

23. M. Mahramanlioglu, I.O. Bicer, T. Misirli and A. Kilislioglu, J. Radioanal. Nucl. Chem., 273, 261 (2007).

24. I. Kizilcikli and M. Mahramanlioglu, Fresenius Environ. Bull., 11(12b), 1098 (2002).

25. C.H. Giles and D.A. Smith, J. Colloid Interf. Sci., 47, 755 (1974). 